International Journal of Linguistics, Literature and Culture
Available online at https://sloap.org/journals/index.php/ijllc/
Vol. 4, No. 4, July 2018, pages: $69 \sim 75$
ISSN: $2455-8028$
https://sloap.org/journals/index.php/ijllc/article/view/268

\title{
Structural Analysis and Religiosity of Balinese Song Lyrics
}

Ida Bagus Nyoman Mantra ${ }^{a}$ Ida Ayu Made Sri Widiastuti ${ }^{\text {b }}$

\section{Article history:}

Received: 15 February 2018

Revised: 26 June 2018

Approved: 19 July 2018

Published: 26 July 2018

\section{Keywords:}

Balinese;

Religious;

Religiosity;

Song Lyrics;

Structural Analysis;

\begin{abstract}
This study examines the lyrics of Balinese religious songs with a primary focus on analyzing the various forms of microstructure, macrostructure, and superstructure of Balinese religious songs by using the Van Dijk discourse analysis. The type of this research is qualitative with the systematic writing of the study which is from theory to deep observation of data for further analysis. The lyrics of Balinese religious songs are literary works containing the traits of lyrical poems that are very beautiful and full of meaning. This study revealed that the lyrics of Balinese religious songs contain microstructure, macros structure, and superstructure. The results of this study provide clear pictures of what religious values are actually in the lyrics of Balinese songs which can be utilized as guidance in establishing a harmonious society.
\end{abstract}

2455-8028 ${ }^{\circledR}$ Copyright 2018. The Author. This is an open-access article under the CC BY-SA license (https://creativecommons.org/licenses/by-sa/4.0/) All rights reserved.

\section{Author correspondence:}

Ida Bagus Nyoman Mantra,

Faculty of Teacher Training and Education,

Mahasaraswati University Denpasar, Jalan Kamboja 11A, Denpasar, Bali, Indonesia

Email address: bagusmantra@hotmail.com

\section{Introduction}

Bali is a well-known tourist destination because of its culture popularity among people around the world. Many people come to Bali to enjoy Balinese culture and get involved in cultural activities. One of the most important cultural activities in Bali is literature readings which are usually carried out in Balinese compound and Balinese village hall. Literature readings are usually done when there is a temple ceremony and also human ceremonies such as birth ceremony, marriage ceremony and death ceremony (Mantra \& Widiastuti, 2014). Literature is part of a culture that has the purpose of helping human beings to reveal the secrets of life which provide meaning to their existence and to open the path of truth because literature is also a way to truth besides religion, philosophy, and science (Mantra, 2017).

The development of Balinese literature as a whole is inseparable from the problems of Balinese daily life which enrich and contribute to Indonesian literature. The existence of Balinese literature then needs to be preserved in order

\footnotetext{
${ }^{a}$ Mahasaraswati University Denpasar, Bali-Indonesia
}

${ }^{\mathrm{b}}$ Mahasaraswati University Denpasar, Bali-Indonesia 
to be used guidance for a better harmonious life in the society. Literary works are part of a culture that has the purpose of helping human beings to reveal the secrets of life which provide meaning to its existence and to open the path of truth. Literary works build the world through words because words have energy. Through that energy formed the image of a certain world as a new world (Kutha Ratna, 2007). The literary works stand alone as a value system. The whole meaning cannot be spelled out only from the author's intent and his time but rather a process of addition throughout the history of criticism from various readers and from several different ages (Wellek and Warren, 1977). In its development, the scope of the literary term is more narrowed its meaning. Literature only covers the field of art which uses language as the medium of transferring. Sometimes, literature in this manner is a form of creation which could be an autonomous creation incoherent with the phenomena at that particular time (Luxemburg, 1986; Mantra \& Widiastuti, 2014).

One of literature that is most admired by the community is oral literature. Oral literature is a literature that encompasses the literary expression of citizens carried out orally. Oral literature is also a culture that is passed down from generation to generation or word of mouth (Hutomo, 1991). Oral literature is part of a culture that has been nurtured by hereditary supporters for generations. This means that oral literature is part of the culture of the society that must be preserved for its existence. Since oral literature is a part of the culture, the scope of oral literature becomes quite extensive. The characteristics of oral literature, among others: (1) spread orally, meaning the expression of culture that is disseminated both in terms of time and space through spoken processes; (2) born from a village-based society, an out-of-town community, or an unknown society; (3) describing the cultural characteristics of one society. In term of oral literature, it can be said as a cultural heritage that portrays the past, but it also mentions new phenomena (in accordance with social issues), therefore oral literature is also called living fossils; (4) poetic pattern; (5) consisting of various versions; (6) illustrating fantasy aspects, the fantasy which is not accepted by modern society but it has a function in society; and (7) using daily spoken language (Hutomo, 1991; Mantra, 2017).

The lyrics of Balinese religious songs can be said as a literary work because they have the characteristics of literature and in the form of discourse. In addition, the lyrics are delivered to the audience orally so that they have more literary meanings. This is in line with Mulyana (2005), the oral discourse has advantages over written discourse to convey more valuable meanings to the bigger number of audience. Some of these advantages are; (1) natural and direct delivery; (2) containing elements of the language prosody (song, intonation); (3) having supra properties (above the sentence structure); and (4) background situational context. Lyrics of songs which are delivered orally have distinctive and beautiful rhythm, high aesthetic values because they are delivered systematically so as to amaze its audience. Balinese song lyrics contain highly educational values which positively benefit the community (Mantra, 2017). Education for the Balinese is considered to be very important in order to be able to live comfortably nowadays in this challenging globalization (Mantra, 2017; Mantra \& Maba, 2018).

Growing popularity of Balinese religious songs amongst the community shows that the increasing desire of the people who want to understand the song lyrics in the context of the daily life of the Balinese society. Religious songs are very meaningful for the community to understand the moral values found in the songs that are useful for a better life. Therefore, this study was conducted to uncover deeply the lyrics of religious Balinese songs to reveal the essence of the lyrics and the value contained the lyrics in the order they can be utilized by the community for their life.

\section{Research Methods}

This study made use of a descriptive qualitative research design. In this study, the natural state of the phenomena was naturally treated in which its condition was well-preserved in order to reveal the actual situation of the data of this study. The researcher conducted a study on the lyrics of Balinese religious songs and then presented the findings descriptively in detail so that deep understanding about the lyrics of Balinese religious songs can be obtained. There were three song lyrics were analyzed in this study. A qualitative method used in this study because this method was closely related to the focus and formulation of research problems of this study.

Qualitative research is done on the natural condition or what it is so that the values and the structure of the lyrics of religious songs can actually be found. The design of qualitative research utilized in this study consisted of three stages, namely (1) preparation stage, (2) field stage, and (3) post-field stage. This research was conducted in Bali province by collecting and analyzing the lyrics of Balinese religious songs. The selected lyrics then be analyzed in depth by applying the discourse theory of Van Dijk in order to reveal the essence of the lyrics of the Balinese religious songs. Data collected in this study, ie macrostructure, microstructure and superstructure of the lyrics of Balinese religious songs. The lyrics of the songs were in the form of recordings that have been circulating in the 
community through various electronic media, the data required in this study was collected by several techniques of documentation study of religious song lyrics. Balinese religious songs were collected first and then transcribed and then translated into Indonesian and English. The collected lyrics were then analyzed and observed by employing Van Dijk's theory. The instrument used was an observation blank sheet with tabulation formats of Van Dijk discourse analysis

\section{Results and Analysis}

The data of this study were collected systematically and deeply analyzed, then described as clearly as possible with inductive argumentative thinking techniques. The inductive process was employed to analyze the smallest data or special data, additionally then the data were specifically tested with various arguments. In this section discussed the structure and religiosity of the lyrics of Balinese religious songs which include macrostructure, microstructure, and superstructure are clarified with detailed and contextual analysis with the life of the Balinese people.

\subsection{Macrostructure (thematic structure)}

Macrostructure is a global meaning of a text that can be understood through its topic. A topic is represented in one or more sentences which becomes the main ideas of a discourse. A topic is also said to be a semantic macrostructure (Van Dijk, 1985: 69). This macrostructure is said to be semantic because when we talk about a topic or theme in a text, we deal with meaning and references found in the text.

Based on the theme, Balinese religious song lyrics entitled Suksma Hyang Widhi showed gratitude to Almighty God. Thanking God Surya was expressed by the song lyric. Moreover, the power of God was symbolized by the flowing of fresh cold wind that never stopped. Acknowledgments were also expressed overall life given by the God and the blessing to all living things. The song lyric entitled Pura Rambut Siwi contains a theme of deep respect for God because He has been keeping the whole world at ease and safe. While the lyric of the song Manusia Pragan Dewa showed the theme of Rwa Bineda occurred is this life. It is about the existence of two different things, for example, a good thing and a bad thing. Rwa Bineda also exists in man, therefore, his behavior always contains two different things.

\subsection{Superstructure}

The superstructure is the structure used to describe schemata which deal with a whole topic or global content of a text. This superstructure organizes topics by arranging sentences or units of text in the desired order or hierarchy of the text or discourse generally has a scheme from the introduction to the end. The plot shows how the parts in the text are arranged and sorted so as to form a unity of meaning.

Based on the superstructure analysis of the song lyric of Suksma Hyang Widhi which consisted of 5 stanzas that include the first stanza is the opening stanza, the second, the third and the fourth stanza are as the contents and the fifth stanza the end closing. The song lyric of Rambut Siwi consisted of 3 stanzas namely the first stanza is as the opening, the second stanza is as the content, and the third stanza is as the end opening. The song lyric of Manusia Pragan Dewa consisted of 5 stanzas. The first stanza is as the opening, second stanza, third, and fourth as the content, the fifth stanza is as the end closing.

In every lyric of the songs discussed above clearly showed that the authors eagerly wanted to convey the theme through a superstructure schematic that includes elements of the text which describes the writer's feelings of God's greatness. Where God has no end to give life and invite all to be with him. In the contents, the authors express gratitude to God for all that has been given to all life in this world. In closing, the authors sincerely expressed gratitude for cares have been given to all beings.

\subsection{Microstructure}

The microstructure is the discourse structure itself envied by some elements of language such as diction and style and other smaller linguistic elements. The microstructure analysis of the Balinese religious songs is an analysis of the lexicon and language style of the text. In general, the Balinese language has three levels of language namely; (1) Highly polite language or the most refined Balinese language is commonly used by the people when talking to religious leaders, and highly respected people; (2) Balinese medium courtesy is the Balinese language expressions

Mantra, I. B. N., \& Widiastuti, I. A. M. S. (2018). Structural analysis and religiosity of Balinese song lyrics. International Journal of Linguistics, Literature and Culture, 4(4), 69-75. https://doi.org/10.21744/ijllc.v4n4.268 
which are commonly used by the community when talking with fellow citizens or people who are in equal position; and (3) ordinary polite language is the language commonly used by people in everyday life.

The song lyric entitled Suksma Hyang Widhi uses words in a subtle language that can easily be understood by the song listener. The words used are appealing words for example words expressing gratitude for all the abundant blessing given by Hyang Widhi or God. In the second line of lyric, there is the word sueca nyuryanin which means willing to give light. In this case, the word 'light' is symbolizing the abundant grace that God gives to human beings in the universe. The word suksma which means 'thank you' is spoken many times on the lyric to emphasize the supplication of God's grace and his abundance to rejoice the mankind. The word suksma is spoken at the end of the song to reemphasize the feeling of gratitude for the fortune that was delegated to human beings.

The song lyric of Rambut Siwi made use of simpler language expressions. The language used is subtle and easy to understand. Overall the song reveals the songwriter's admiration of the greatness of Batara Sakti at Pura Rambut Siwi as a manifestation of God. The Selection of words shows the authenticity of Balinese Hindus in worshiping and admiring the greatness of God by always maintaining and preserving the temple where he is revered. The use of Balinese language is showing the expressions of being proud and prostrate to the greatness of God, and to all manifestations of the Almighty God.

The song entitled Manusa Peragan Dewa uses diction expressing subtle expression of singgih or highly polite language. This song explained the behavior of people living in the world. There are good people and some are always doing evil. The use of the most polite language aims to show the strata of life of human beings. This also indicates that the song delivered has a very profound meaning and it is obliged to be understood by the listener. There are some words that are difficult to understand by those who rarely use subtle languages. The existence of good and bad human nature in the world is also reinforced by the statement of rwa bhineda which means good and bad which are always side by side. The Overall words used in this song are subtle language forms that can only be understood by people who are used to use the language.

Based on the results of diction analysis in all three songs, it can be concluded that Balinese religious songs mostly use words with subtle language or singgih which is highly polite expressions and delicately sung to express gratitude and respect. The selection of the words indicates that Balinese religious songs were created to express the greatness of God, the thankfulness of the grace that was bestowed and the honor of mankind in the life of society. The selection of words in the subtle language has the goal that the message conveyed in the religious song of Bali has a function to always remind and invite human beings to continually be grateful, to obey God's teachings and to keep the universe and its contents in harmony.

The language styles used by the songwriters are very specific in order to meaningfully express the greatness of the God. The language styles were constructed strongly to convey the writers' ideas using beautiful and harmonious language styles to create an atmosphere that can touch the emotional and intellectual power of the listeners. The language styles used in Balinese religious song lyrics in this study use the symbolic, parable, and personification of language styles to emphasize the meaning of the song. The words Ida Sang Hyang Surya and Ida Sang Hyang Bayu in the lyrics of the song Suksma Hyang Widhi symbolizing the God who has a manifestation as the Sun God who shines the universe and Wind God who gives wind and energy to all life in this world.

The song titled Pura Rambut Siwi used the parable style. The style of the language is found in the lyrics for example 'rambut suci Ida pinaka bukti'. In this song, the greatness of God manifestation named 'Batara Sakt' symbolized by his hair adored in a great temple in Bali called Pura Rambut Siwi. God's greatness is symbolized by the embodiment of God's revered hair as proof of his greatness that always bestows his grace upon mankind. The song Manusa Peragan Dewa used a language style of symbolic language. It found in the lyrics 'manah sane kaon, punika bhuta ngrebeda, kayun sane becik, punika god sane metangi'. The bad thought is symbolized by the annoying Bhuta. A good thought is symbolized by the wake of God. The words contained in Balinese religious song text are cursory all seem to mean denotative. In addition to meaningful denotative words also conveyed using polite Balinese language. With the use of polite Balinese language, Balinese religious song texts become more meaningful for the people of Bali.

The religious values found in Balinese song lyrics are considered as reflections of Balinese way of life in which worshiping the God is always in heart of every Balinese. Devotion to the existence of God becomes a most important activity for Balinese which is celebrated daily. Singing Balinese religious songs are also becoming popular among Balinese community as an effort to thank God for his blessing and kindness in keeping safe and prosperous life for all beings. 


\section{Conclusion}

The lyrics of Balinese religious songs are classified as written literature which is orally spoken and orally distributed and inherited by word of mouth. Judging from the medium of delivery, the discourse of Balinese religious songs belong to verbal mixed folklore because the verbal process originated from the written discourse that verbally delivered to the listeners. Moreover, Balinese song lyrics are free poems as a medium to express ideas, thought, messages, advice, directions to be conveyed by the author and singer. The words in Balinese religious song lyrics are structured in order to be able to express a special meaning according to the context.

The text of Balinese religious songs in this study was analyzed based on a critical discourse approach developed by Van Dijk. The utilization of Van Dijk approach was intended to study in depth in order to reveal the text structure of Balinese religious songs as a whole. By studying macrostructures, superstructures, and microstructures can be found various cultural and linguistic aspects revealed in the text of Balinese religious songs. The Balinese religious songs are found to have highly rich words of the greatness of God and words of gratitude. These findings suggest that the songwriters should continually create more meaningful songs and the communities are also suggested to diligently learn the songs to create harmonious life.

\section{Conflict of interest statement and funding sources}

The authors declared that they have no competing interest. The study was financed by institution funding.

\section{Statement of authorship}

The authors have a responsibility for the conception and design of the study. The authors have approved the final article.

\section{Acknowledgments}

We would like to sincerely express our gratitude to all educators, researchers, songwriters and Balinese singers who have contributed any assistance during the conduction of this study and during the process of the writing of this article. 


\section{References}

Cahyani, I. A. M., Mantra, I. B. N., \& Wirastuti, I. G. A. P. (2018). Employing Picture Description to Assess the Students' Descriptive Paragraph Writing. Soshum: Jurnal Sosial dan Humaniora, 8(1), 86-93.

Hutomo, S. S. (1991). Mutiara yang terlupakan: Pengantar studi sastra lisan. Himpunan Sarjana Kesusastraan Indonesia, Komisariat Jawa Timur.

Lindayani, L. R., Masri, F. A., Idul, R., \& Sawali, L. (2018). A metaphorical analysis of Kabhanti Modero to show Munanese social relations. International Journal of Linguistics, Literature and Culture (IJLLC), 4(2), 72-80.

Luxemburg, J. J. H., Bal, M. G., Weststeijn, W. G., \& Hartoko, D. (1989). Pengantar ilmu sastra. Penerbit PT Gramedia.

Mantra, I. B. N. (2016). Promoting Primary School Teachers' Competence through Dynamic Interactive Workshop and Partnership. Journal of College and University. This is an open access article under the, 2455, 8028.

Mantra, I. B. N. (2017). Promoting the students'writing skill through folktales based learning activities.

Mantra, I. B. N., \& Maba, W. (2018). Enhancing the EFl learners' speaking skill through folktales based instruction. In SHS Web of Conferences (Vol. 42). EDP Sciences.

Mantra, I. B. N., \& Widiastuti, I. M. S. (2014). Fungsi Dan Makna Tradisi Lisan Genjek Kadong Iseng. Jurnal Bakti Saraswati (JBS), 3(02).

Mantra, I.B.N. (2017). Teks Lisan Genjek di Kabupaten Karangasem. Doctoral Dissertation. Denpasar: Udayana

Mulyana, D. (2005). Kajian Wacana: Teori, Metode, dan Aplikasi Prinsip-prinsip Analisis Wacana. Yogyakarta: Tiara Wacana.

Ratna, N. K. (2007). Sastra dan cultural studies: representasi fiksi dan fakta. Pustaka Pelajar.

Riana, I. K., Simpen, I. W., \& Ola, S. S. (2018). Supernatural signification system amuf on death ritual speech nen fen nahat neu nitu in boti society. International Journal of Linguistics, Literature and Culture (IJLLC), 4(2), 4657.

Suarta, I., Widana, I. W., \& Citrawan, I. W. (2018). Lontar manuscript readability. International Journal Of Linguistics, Literature And Culture, 4(2), 58-65.

University

Van Dijk, T. A. (1985). Handbook of discourse analysis. In Discourse and dialogue.

Wellek, R., \& Warren, A. (1956). Theory of literature (p. 78). New York: Harcourt, Brace \& World. 


\section{Biography of Authors}

\begin{tabular}{|l|l|}
\hline \hline & $\begin{array}{l}\text { Dr. Ida Bagus Nyoman Mantra, SH., S.Pd., M.Pd is a Doctor in Linguistics from } \\
\text { Udayana University and holds a master degree in education from Ganesha Education } \\
\text { University. He is a lecturer in English language Education at Mahasaraswati } \\
\text { University Denpasar, Bali. He is teaching various subjects namely: English language } \\
\text { teaching methods, research methodology, curriculum and materials development and } \\
\text { textbook analysis. He has carried out several studies in language education, linguistics, } \\
\text { oral tradition and human right laws. His study focus is on investigating functions, } \\
\text { values, and meanings of Balinese oral tradition including micro and macro linguistics. } \\
\text { His academic papers have been published in several national education and linguistics } \\
\text { journals. }\end{array}$ \\
\hline & $\begin{array}{l}\text { Ida Ayu Made Sri Widiastuti, S.Pd., M.Pd., M.Hum is a doctoral student of English } \\
\text { language teaching at the State University of Malang, East Java. She has carried out } \\
\text { extensive studies on language development and assessment. She is currently } \\
\text { conducting in-depth and intensive study on various assessment types of English } \\
\text { language teaching. Her academic papers have been published by several national and } \\
\text { international publishers. She has written several books on language teaching, literature, } \\
\text { and hospitality. }\end{array}$ \\
\hline
\end{tabular}

Mantra, I. B. N., \& Widiastuti, I. A. M. S. (2018). Structural analysis and religiosity of Balinese song lyrics. International Journal of Linguistics, Literature and Culture, 4(4), 69-75. https://doi.org/10.21744/ijllc.v4n4.268 